$\xi=-1$

\title{
Choice Recommendations for Rational Concreting Technology of Steel Reinforced Concrete Structures
}

\author{
Tatiana Nikiforova ${ }^{1}$, Olga Gukasian ${ }^{2 *}$, Nataliia Mahas ${ }^{3}$. \\ ${ }^{1}$ State Higher Education Establishment "Prydneprovsk State Academy Of Civil Engineering And Architecture", Ukraine \\ ${ }^{2}$ Poltava National Technical Yuri Kondratyuk University, Ukraine \\ ${ }^{3}$ Poltava National Technical Yuri Kondratyuk University, Ukraine \\ *Corresponding Author E-Mail: Olg.Gukasyan@Gmail.Com
}

\begin{abstract}
In this work the experimental research cycle is described. This cycle is an affect studying of the most widespread concrete defect types, such as concrete core weakening is an inclusion of the "weak" concrete, the presence of emptiness, concrete heterogeneous by the height. The research of the manufacturing conditions affect of combine concrete core structures and the elements of physical and mechanical characteristics changing are on the experimental research base. On the researches testing base of samples with special form and given sizes the concrete strength value is appreciated. The different variants of strength decreasing on the researched element height are analyzed by the conducted testing results of the steel reinforced concrete structures. As a result of the conducted tests, the work conditions coefficient and the steel reinforced concrete elements concreting technology were formulated.
\end{abstract}

Keywords: concrete, concrete technology, coefficient of the work conditions reliability by the material, steel reinforced concrete, strength

\section{Introduction}

Steel reinforced concrete structures are the main part of modern civil and industrial construction. Such constructive elements combine steel rolling work, including sheet metal, and concrete, both unrecorded and recorded by rod valves. The concrete quality in steel reinforced concrete structures essentially depends on its production technology. As a result of the complicated conditions presence of concreting (concrete mixture pouring in forms) with a fairly low production culture of large concrete parts, risks of concrete core defects formation are appeared (stratification, cavity, variability of the concrete strength on the height of the element, cracks and so on). Detection and taking into account the laws of formation of heterogeneous concrete core strength of these elements on the height need special attention when strength is evaluated and projection level of steel reinforced concrete structures reliability is provided.

\section{Overview of the Latest Research Sources and Publications}

Nowadays some complex steel reinforced concrete structures types are well known and implemented in construction practice. They are: with external entire (pipe concrete), throughout (bar elements, and elements that are aroused when steel throughout columns cavity are concreted) and laminated (one-sided, doublesided, three-sided) reinforcement; steel-concrete with rigid armature; steel structures with concreting compressed elements. Its compatible work with concrete is provided by specific approaches- by anchors, detents, gluing, frictional connections and others [1]. Therefore, all possible combinations of the rolled steel are belonged to steel reinforced concrete, except such structures that are used only rolled steel as core armature.

The concrete should be highlighted from parts of the steel reinforced concrete structures as the changing material. The concrete structure [2,3] greatly affects on its physical and mechanical properties and depends on water-cement relation (W/C). The concrete density decreases with excess unbound water, pores can take near a third of the cement stone volume that causes decreasing of concrete strength. The concrete structure is heterogeneous. It is the spatial grate from the cement stone that is filled with grains of sand and gravel of different magnitude and form with large quantity of micro pores and capillaries. Chemically unbound water, water vapor and air are in these capillaries [11]. The mass integrity in concrete is broken. Herewith, the cement stone is also heterogeneous by structure and consists of spring crystal and viscous mass that fills it.

The characteristic concrete feature is that its structure changes with time passing through the changing water balance, decreasing volume of hardening gel, increasing spring crystal splits. The concrete volume decreasing (contraction) is happened. It depends on such reasons: quantity and kind of cement, water quantity, size and kind of filler.

The intensity of contraction increasing deformations depends on environment humidity, character of capacities that have an impact on concrete. The contraction is completely connected with physical and chemical processes of concrete hardening that cause decreasing of cement gel volume. Due to this, starting tension appears in the cement stone through the obstacles to the fillings contraction. These capacities are uneven by means of the drying out irregularity in element section that cause the nascence of the contraction cracks in concrete. 


\section{Defining Parts of General Problem which were Not Yet Investigated}

Unlike domestic norms in European normative document EN 1992 Eurocode 2: Design of concrete structures. EN 1992-1-1:2004 Part 1-1: General rules and rules for building (EC2) [4] the value of concrete normative strength variability with axial compression is not shown. Despite this, its average and characteristic values are shown and we are able to count the appropriate variation coefficient. Its value changes in the range of 24 to $9 \%$ and decreases with increasing of concrete class. It should be noticed that modern normalized concrete classes are located with a large interval comparatively to normative strength changing $\left(\mathrm{V}_{\mathrm{c}}=13,5 \%\right)$ [5]. The application of non-destructive methods for concrete strength control, as a rule, causes the factual coefficient variation of concrete strength increasing. As a result, it causes even more "overlay" distributions $[6,12]$. The advantages and disadvantages are closely researched in works $[7,8]$.

\section{Aims and Objectives}

The carrying ability and the tense-deformed state of steel reinforced concrete elements depend on the constructive decision, the capacity apposition eccentricity and physical-mechanical properties of the source materials. It is decided to determine experimentally the strength and work features under the steel reinforced concrete construction capacity.

\section{Results}

For weak areas, determination of steel reinforced concrete elements the experimental researches are conducted [9]. They contain two stages:

the first step is samples of throughout steel reinforced concrete elements with external sheet reinforcement (Fig. 1); the second step is concrete prisms samples (Fig. 3).

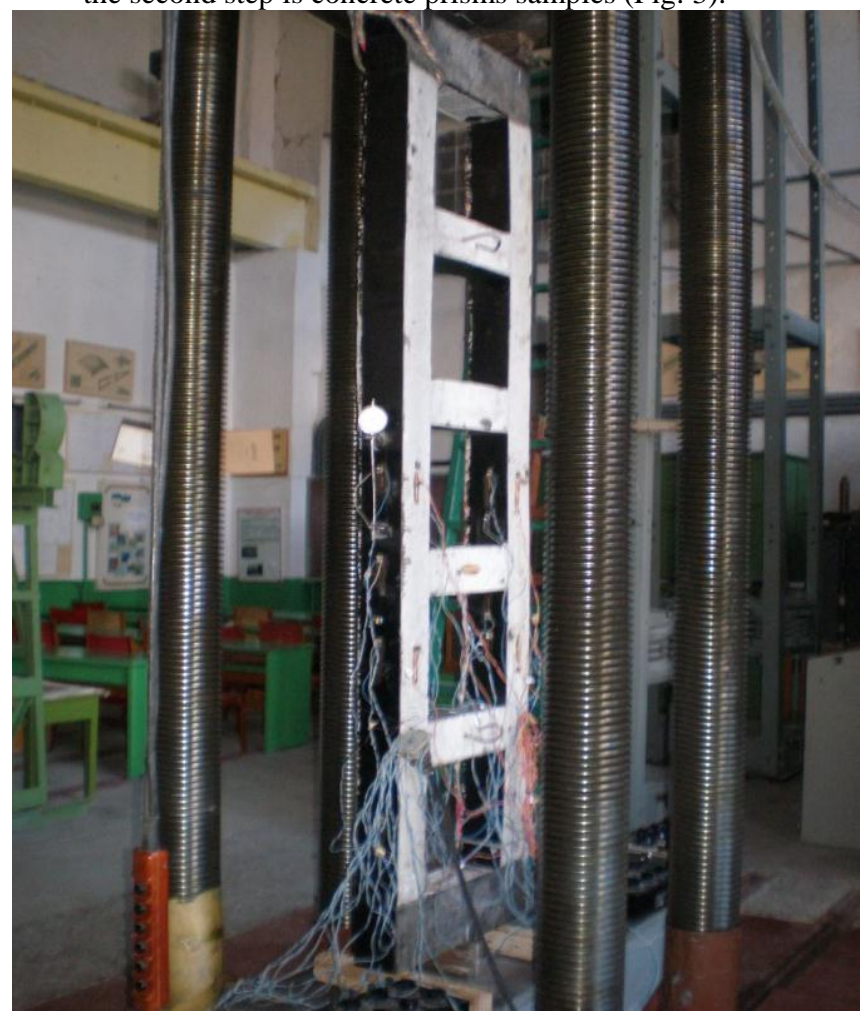

Fig. 1: The General view of experimental samples of series CFST-1 and series CFST -2
The samples of the first experimental step are complex steel reinforced concrete structures that are consisted with two parts: fabrication of frames and manufacturing of samples.

For manufacturing of experimental samples the steel sheet $\mathrm{t}=4 \mathrm{~mm}$, $\mathrm{t}=10 \mathrm{~mm}$ and the transverse armature with $\varnothing 6 \mathrm{~mm}$ class are applied. The sample height is $2200 \mathrm{~mm}$. The width is $500 \mathrm{~mm}$. The concrete class is $\mathrm{C} 30 / 35$.

Tests were conducted on samples that are made in two options monolithic (CFST-1) and collective (CFST-2). Samples were loaded gradually and had to be destroyed. For carrying ability expenditure of throughout steel reinforced concrete elements that are tested on compression, the force $\mathrm{N}$ is accepted. This force corresponded to the cracks appearance in knots and full construction destroying. The carrying ability of researched samples for monolithic and collective variants is shown in table 1 .

As we could see from table 1, when the force is applied to the monolithic samples with a scheme, capacity central compression (series CFST-1) on the longitudinal sample axis through the traverse (upper span), the carrying ability was much less and it was $240 \mathrm{kN}$ at all. The carrying ability sample expenditure happened due to the destruction of the spacing that does not bear the significant bending moment. Such a moment arose during the transfer of the concentrated force.

In the series CFST-1 samples, steel sheets reinforced the upper spacing during manufacturing. That is why, the samples carrying ability was essentially higher than in the monolithic variant and it was $382 \mathrm{kN}$. In that case, the carrying ability was lost due to spacing destruction from the local action of the bending moment. The capacity was transmitted through the spacing. It should be mentioned that the overall stability expenditure was not determined in no case in all of tested compressed samples. The applied cylindrical hinges do not allow it from samples plane. The horizontal samples movement was insignificant in samples plane. Even reaching the carrying ability expenditures, none of the tested samples lost their integrity. It confirms its high reliability.

The destruction character of structures knots tested on compression, we can see on Fig. 2.

Table 1. The carrying ability of researched samples while compression testing

\begin{tabular}{|c|c|c|c|}
\hline $\begin{array}{c}\text { The samples } \\
\text { series }\end{array}$ & $\begin{array}{c}\text { The structure } \\
\text { variant }\end{array}$ & The loading type & $\begin{array}{c}\mathrm{N}, \\
\mathrm{kN}\end{array}$ \\
\hline CFST -1 & monolithic & central compression & 240 \\
\hline CFST-2 & collective & central compression & 382 \\
\hline
\end{tabular}

The experimental research program was compiled considering the affect on the carrying ability and researched elements deformation, the method of structures manufacturing, application capacities schemes. The accepted experimental research methodic and measuring instruments, that have been tested, allow to get the objective scheme of the throughout steel-concrete structures work properties with an external sheet reinforcement.

Analyzing the destruction character of the researched samples, one can recommend strengthening the construction knots by internal core reinforcement or external overlays in further projecting and researching. In addition, we can apply the stronger concrete with the concrete quality control.

The second step of the experimental research series «CS» is for examining of the technology manufacturing affect of steel reinforced concrete elements on concrete samples prisms strength changing due to the height.

The concrete prisms methodology predicted the layered form filling by means of concrete mixtures with different strength. Herewith, the average expenditure of the binders for all samples is the same (Fig.3). The concrete samples strength of the «CS» series is examined by two methods: by compression and non-destructive method. The testing methodology was developed for concrete strength homogeneity determination according to the samples height. The strength changing determination on the concrete samples-prisms height series «CS» by the non-destructive method (sclerometer) was executed on two samples of each series (table 2, Fig. 4). 

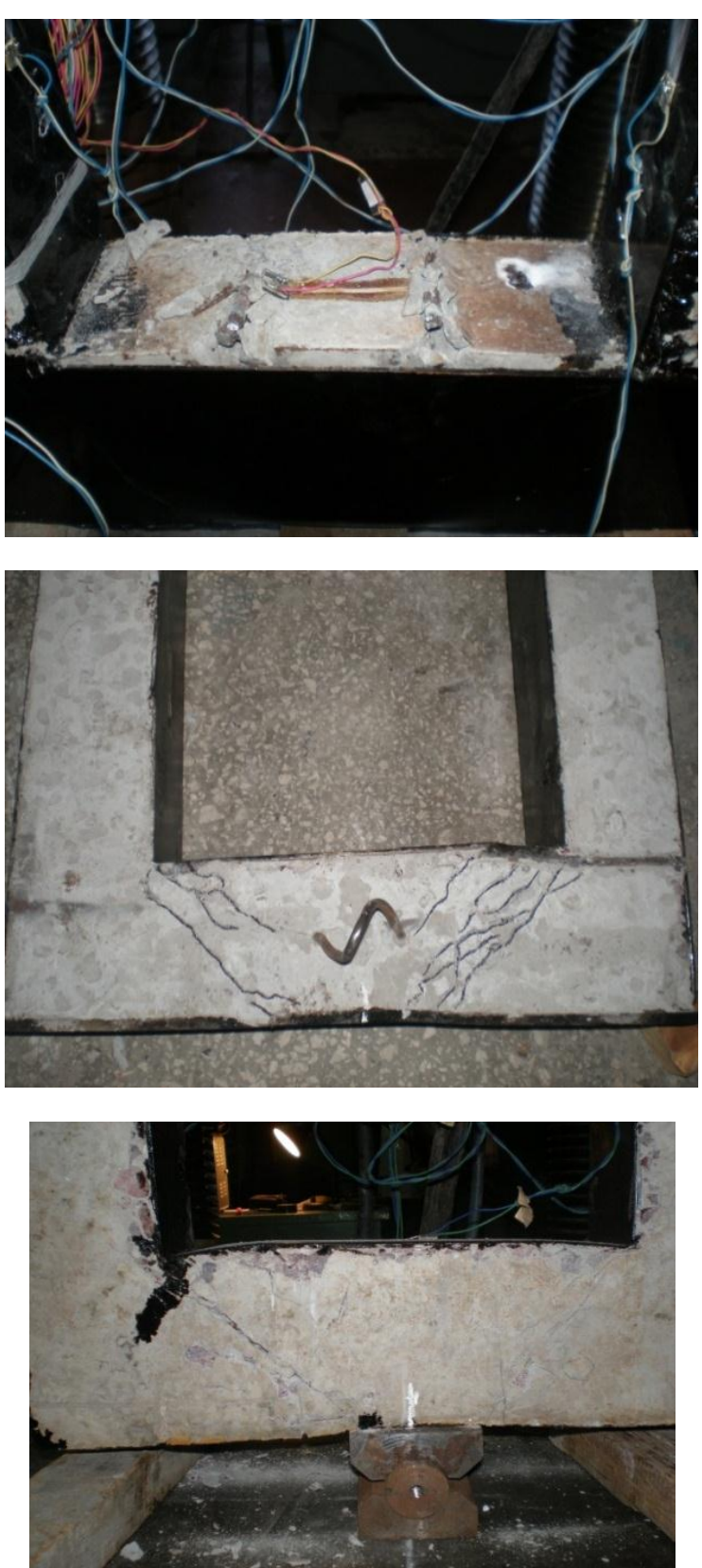

Fig. 2: The destroying character of construction knots tested on compression

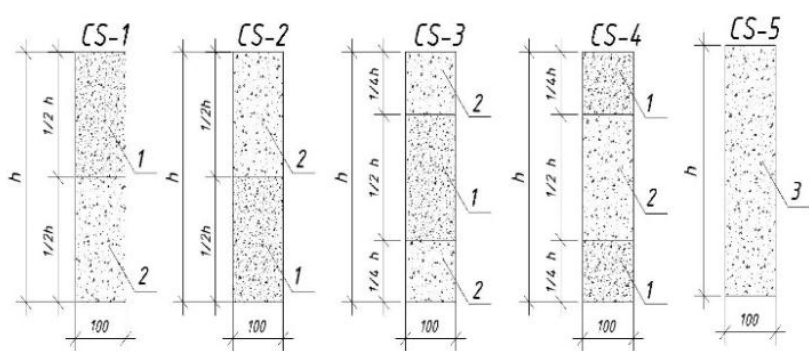

Fig. 3: The samples-prisms concrete scheme

1 - the cement expenditure on the $1 \mathrm{~m}^{3}$ concrete $450 \mathrm{~kg} ; 2$ - the cement expenditure on the $1 \mathrm{~m}^{3}$ concrete $250 \mathrm{~kg} ; 3$ - the cement expenditure on the $1 \mathrm{~m}^{3}$ concrete $350 \mathrm{~kg}$

Table 2. The testing results of concrete samples-prisms strength

\begin{tabular}{|c|c|c|c|c|c|}
\hline \multirow[b]{2}{*}{$\cdot \stackrel{\mathscr{e}}{\bar{D}}$} & \multirow{2}{*}{$\begin{array}{l}\text { The sam- } \\
\text { ples con- } \\
\text { creting } \\
\text { methodol- } \\
\text { ogy and the } \\
\text { localization }\end{array}$} & \multicolumn{2}{|c|}{$\begin{array}{l}\text { The researching methods of } \\
\text { concrete strength }\end{array}$} & \multicolumn{2}{|c|}{$\begin{array}{l}\text { The determination } \\
\text { results of layers con- } \\
\text { crete sample strength } \\
\text { and on compression }\end{array}$} \\
\hline & & $\begin{array}{l}\text { The re- } \\
\text { searched }\end{array}$ & $\begin{array}{l}\text { The strength } \\
\text { characteris- }\end{array}$ & $\begin{array}{l}1 \text { sample } \\
\mathrm{MPa}\end{array}$ & $\begin{array}{l}2 \\
\text { sam- }\end{array}$ \\
\hline
\end{tabular}

\begin{tabular}{|c|c|c|c|c|c|}
\hline & $\begin{array}{l}\text { place of } \\
\text { concrete } \\
\text { with lower } \\
\text { strength }\end{array}$ & method & tics & & $\begin{array}{l}\text { ple } \\
\mathrm{MPa}\end{array}$ \\
\hline \multirow[b]{2}{*}{$\overrightarrow{\dot{v}}$} & \multirow{2}{*}{$\begin{array}{l}\text { the con- } \\
\text { crete } \\
\text { strength } \\
\text { weakening } \\
\text { on } 1 / 2 h \text { in } \\
\text { the lower } \\
\text { samples } \\
\text { part }\end{array}$} & $\begin{array}{c}\text { Non- } \\
\text { destructive } \\
\text { method }\end{array}$ & $\begin{array}{l}f_{1} \\
f_{2}\end{array}$ & $\begin{array}{l}41,38 \\
21,92 \\
\end{array}$ & $\begin{array}{l}39,94 \\
23,00\end{array}$ \\
\hline & & $\begin{array}{c}\text { Test on } \\
\text { compres- } \\
\text { sion }\end{array}$ & $f_{\mathrm{c}, \mathrm{cul}}$ & 16,21 & 15,72 \\
\hline \multirow[b]{2}{*}{$\stackrel{\sim}{u}$} & \multirow{2}{*}{$\begin{array}{l}\text { the con- } \\
\text { crete } \\
\text { strength } \\
\text { weakening } \\
\text { on } 1 / 2 h \text { in } \\
\text { the upper } \\
\text { samples } \\
\text { part }\end{array}$} & $\begin{array}{c}\text { Non- } \\
\text { destructive } \\
\text { method }\end{array}$ & $\begin{array}{l}f_{2} \\
f_{1}\end{array}$ & $\begin{array}{l}21,52 \\
39,96 \\
\end{array}$ & $\begin{array}{l}19,68 \\
43,20\end{array}$ \\
\hline & & $\begin{array}{c}\text { Test on } \\
\text { compres- } \\
\text { sion }\end{array}$ & $f_{\mathrm{c}, \mathrm{cul}}$ & 19,18 & 18,79 \\
\hline \multirow[b]{2}{*}{$\hat{n}$} & \multirow{2}{*}{$\begin{array}{l}\text { the strength } \\
\text { weakening } \\
\text { on } 1 / 4 h \\
\text { from the } \\
\text { samples } \\
\text { ends }\end{array}$} & $\begin{array}{c}\text { Non- } \\
\text { destructive } \\
\text { method } \\
\end{array}$ & $\begin{array}{l}f_{2} \\
f_{1} \\
f_{2} \\
\end{array}$ & $\begin{array}{l}24,57 \\
44,13 \\
28,30 \\
\end{array}$ & $\begin{array}{c}23,93 \\
45,50 \\
24,8 \\
\end{array}$ \\
\hline & & $\begin{array}{c}\text { Test on } \\
\text { compres- } \\
\text { sion } \\
\end{array}$ & $f_{\mathrm{c}, \mathrm{cul}}$ & $\mathbf{2 0 , 5 7}$ & 20,37 \\
\hline \multirow[b]{2}{*}{ נ̀ } & \multirow{2}{*}{$\begin{array}{l}\text { the strength } \\
\text { weakening } \\
\text { on } 1 / 2 h \text { in } \\
\text { the samples }\end{array}$} & $\begin{array}{c}\text { Non- } \\
\text { destructive } \\
\text { method } \\
\end{array}$ & $\begin{array}{l}f_{1} \\
f_{2} \\
f_{1} \\
\end{array}$ & $\begin{array}{l}44,37 \\
22,85 \\
46,57 \\
\end{array}$ & $\begin{array}{l}44,20 \\
24,75 \\
38,57 \\
\end{array}$ \\
\hline & & $\begin{array}{c}\text { Test on } \\
\text { compres- } \\
\text { sion } \\
\end{array}$ & $f_{\mathrm{c}, \mathrm{cul}}$ & 22,76 & 22,84 \\
\hline \multirow[b]{2}{*}{$\ddot{n}$} & \multirow{2}{*}{$\begin{array}{l}\text { the one } \\
\text { strength } \\
\text { concrete } \\
\text { throughout } \\
\text { samples } \\
\text { height }\end{array}$} & $\begin{array}{c}\text { Non- } \\
\text { destructive } \\
\text { method }\end{array}$ & $f_{3}$ & 33,50 & 34 \\
\hline & & $\begin{array}{c}\text { Test on } \\
\text { compres- } \\
\text { sion }\end{array}$ & $f_{\mathrm{c}, \mathrm{cul}}$ & 22,51 & 22,54 \\
\hline
\end{tabular}

The experimental samples are conditionally divided according to their height on 10 equal fragments. The average value of fragment strength is found and investigated by non-destructive method.

The average value of concrete strength is calculated for each layer $f_{1}$ (the cement expenditure on the $1 \mathrm{~m}^{3}$ concrete $450 \mathrm{~kg}$ ), $f_{2}$ (the cement expenditure on the $1 \mathrm{~m}^{3}$ concrete $250 \mathrm{~kg}$ ), та $f_{3}$ (the cement expenditure on the $1 \mathrm{~m}^{3}$ concrete $350 \mathrm{~kg}$ ). After this, samples are destroyed on the press $\left(f_{c, c u l}\right)$.

It should be admitted, that the series CS-3 samples (the strength weakening on $1 / 4 l$ from the samples ends) have the highest average values of strength on the compression. It is $1 \%$ higher than control samples (series CS-5), and this concrete strength fluctuation is in the mistakes limits. The average value decreasing of samples strength from $9 \%$ to $30 \%$ is characteristic for other samples.

If we compare testing results by compression and by nondestructive method, so it should be mentioned that the average values difference could differ twice (f.e. series CS-1 samples).

The concrete strength fluctuations by the height and the samples destructive character are considered on the Fig. 4.

a)CS-1

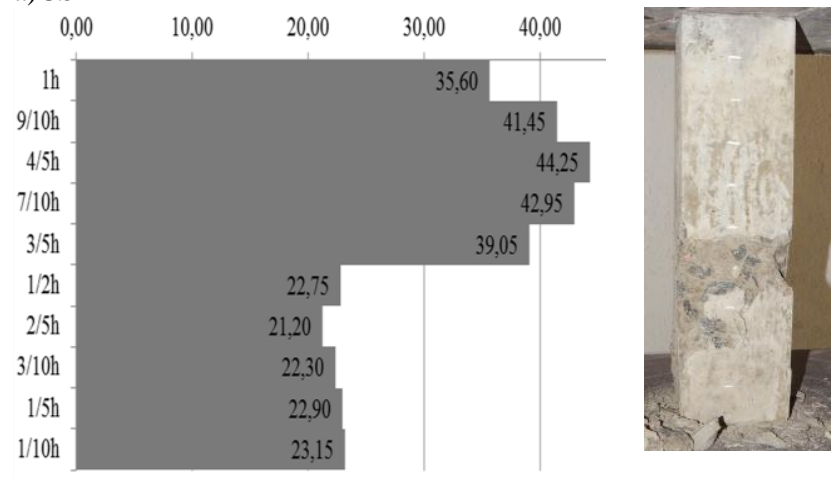

b) $\mathrm{CS}-2$ 

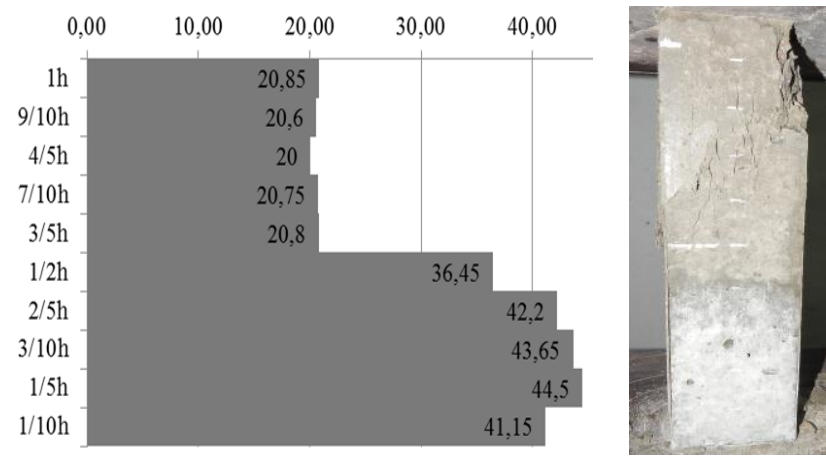

c) $\mathrm{CS}-3$
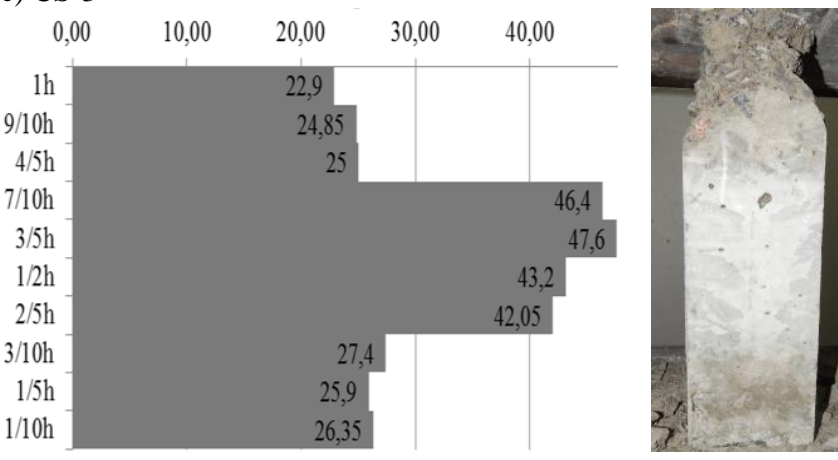

c) $\mathrm{CS}-3$

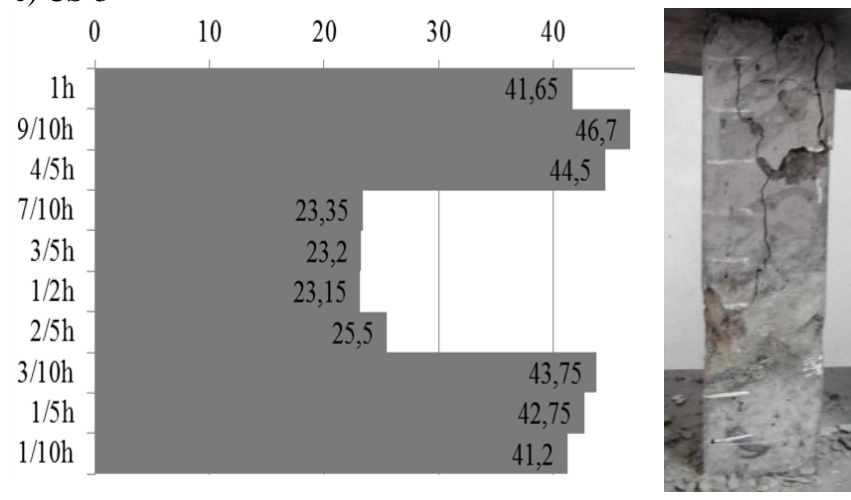

Fig. 4: The destructive samples character that are tested on the compression

The coefficient of strength variation on concrete compression of series «CS» samples is calculated $V_{\mathrm{cr}}=13 \%$ by the conducted testing results. The variation coefficient is determined $\mathrm{V}_{\text {нер. }}=5 \%$ by the average strength value and by the non-destructive method Herewith, the variation coefficient is fluctuated from $29 \%$ to $36 \%$ for samples CS-1, CS-2, CS-3 та CS-4, when strength on the samples height is determining by the non-destructive method.

As a result of conducted experiments, one can calculate the coefficient of the concrete work conditions. Such coefficient we can use when the pipe-concrete structures calculation, as the transferable coefficient from the proposed concrete core strength to the real strength. While this coefficient is calculated, the average and the minimum concrete strength are applied [10].

The average concrete strength of the weakest concrete area could be determined by the formula:

$f_{c m, \min }=\gamma_{c, t} \cdot f_{c m}$

where $f_{c m}-$ is the factual value of the average concrete strength of control concrete samples;

$\gamma_{c, t}-$ is a partial coefficient of the work conditions reliability by the material that characterizes the technological concrete heterogeneity in the product.
The results of the conducted experimental research have confirmed the necessity of possible heterogeneity consideration of the constructive elements (products) concrete strength that have the complicated concrete conditions. The characteristic example of these products is steel reinforced concrete structures. After all, the essential risks of the concrete core defects formation (stratification, cavity, pores, cracks, samples strength changing by its height, etc.) have place here, when the concrete mixture is laying out in the closed formwork space. The identification and consideration of forming regularities of the heterogeneous concrete strength by its height need the special attention at probabilistic work analysis and at the indicators reliability elements evaluation at all.

In connection, the average concrete strength determination methodology is offered during the concrete composition selection on the ICP factory when moving from its project class to the average strength. The mark allows taking into account statistically significant difference between the average strength of the concrete control samples and the average strength of the concrete product from the software condition strength of its least weak zone no less than $95 \%$ from the project.

\section{Conclusions}

The results of the conducted experimental research and its analysis have confirmed the necessity of possible heterogeneity consideration of the constructive elements (products) concrete strength that have the complicated concreting conditions. The characteristic example of these products is steel reinforced concrete structures. After all, the essential risks of the concrete core defects formation (stratification, cavity, pores, cracks, samples strength changing by its height, etc.) have place here, when the concrete mixture is laying out in the closed formwork space. The identification and the consideration of forming regularities of the heterogeneous concrete strength by its height need the special attention at probabilistic work analyze and at the indicators reliability elements evaluation at all.

In connection, the average concrete strength determination methodology is offered during the concrete composition selection on the ICP factory when moving from its project class to the average strength. The mark allows taking into account statistically significant difference between the average strength of the concrete control samples and the average strength of the concrete product from the software condition strength of its least weak zone no less than 95\% from the project.

The necessity of applying the additional partial coefficient of the reliability by the material is substantiated. This technological coefficient takes into account additional (first and second) concrete heterogeneity of long steel reinforced concrete elements under complex concreting conditions (vertical supply of the concrete mixture on the building square) depending on the technological parameters of the concrete mixture and its consolidation regimes.

The conducted testing results witness that the concrete strength changing by its height depends on the mark of the concrete mixture for easy layouts. So, the strength variation coefficient of the concrete core by the pipe-concrete elements height when the rigid concrete mixtures are applying (V4) in 1,5 ...3,5 times bigger than for mobile (S1 та S2). The statistically essential correlation connection between the consolidation time and concrete strength was found only while rigid mixtures (V4) and mobile mixtures with a draft of a cone $1-4 \mathrm{~cm}(\mathrm{~S} 1)$ are applied. From this point of view, the vibration time 2 min. should be recommended, as the optimal regime of the concrete consolidation. The general variation coefficient of the concrete strength by its height is near the $13 \%$ when the mobile mixtures with a draft of a cone $4-9 \mathrm{~cm}$ are applying and not depending on the time of their consolidation.

The concrete strength changing (variation coefficient) in the product could be recommended $20 \%$ (for the rigid) and $16 \%$ (for mixtures with a draft of a cone $2,5 \mathrm{~cm}-$ for $\mathrm{S} 1$ ). It was determined by the own experimental results for the average concrete strength part correction for racks manufacturing. When the mobile concrete 
mixtures with a draft of a cone $5 \ldots 9 \mathrm{~cm}$ - for S2 applied, we can use the standard changing value for the concrete strength-13,5\%.

The generalized recommendations for pipe-concrete elements concreting.

\section{References}

[1] Semko OV Imovirnisni aspekty rozrakhunku stalezalizobetonnykh konstruktsii, Monograph, Kiev, 316 (2004)

[2] P.V. Krivenko, Budivelne materialoznavstvo, Monograph, Kiev, 704 (2006)

[3] S.M.R. Tabatabai, K.M. Mosalam, (2001) "Computational platform for non-linear analysis/ optimal design of reinforced concrete structures", Engineering Computations, Vol. 18 Issue: 5/6, pp.726743, https://doi.org/10.1108/EUM0000000005785

[4] Design of composite steel and concrete structures - Part 1-1: General Rules and Rules for Bridges. EN 1994-1: 2001. Eurocode 4, Brussels, 96 (2006)

[5] Semko OV, Voskobiinyk OP, Keruvannia ryzykamy pry proektuvanni ta ekspluatatsii stalezalizobetonnykh konstruktsii Monograph, Poltava, 514 (2012)

[6] Bruce Ellingwood Theodore V. Galambos, Probability-based criteria for structural design, https://doi.org/10.1016/01674730(82)90012-1

[7] Tjiang Arif Gunadi, Herman Parung, Abd Rachman Djamaluddin, A Arwin Amiruddin, Design of reinforced areas of concrete column using quadratic polynomials, doi:10.1088/1757899X/271/1/012098, http://iopscience.iop.org/article/10.1088/1757899X/271/1/012098/ pdf

[8] Repair and strengthening of concrete structures July 07, 2015 https://doi.org/10.1680/frasocs.16156.fm

[9] N.M. Mahas, «Keruvannia ryzykamy pry proektuvanni ta ekspluatatsii stalezalizobetonnykh konstruktsii», Poltava, (2016) p $245-261$

[10] Voskobiinyk Olena, Gukasian Olga «Study of technological features of tubular compressed concrete members in concreting», MATEC Web of Conferences, Vol.116, No.02037, (2017). DOI 10.1051/matecconf/20171160203 Transbud-2017 (Scopus) https://www.matecconferences.org/articles/matecconf/abs/2017/30/

matecconf_trs2017_02037/matecconf_trs2017_02037.html

[11] Storozhenko, L., Butsky, V., Taranovsky, O. Stability of Compressed Steel Concrete Composite Tubular Columns with Centrifuged Cores // Journal of constructional steel research; 46, 1/3; 484; Second World Conference on Steel in Construction ; 1998.

[12] Piskunov, V.G., Gorik, A.. \& Cherednikov, V.N. Mechanics of Composite Materials (2000) 36: 445. https://doi.org/10.1023/A:1006798314569 